SUSTAINABLE FORESTRY

COLLECTION 69-70, 2014
ODRŽIVO ŠUMARSTVO

ZBORNIK RADOVA 69-70, 2014

UDK $630 * 416(497.11) " 2013 "=111$

Original scientific paper

\title{
ANALYSIS OF TYPES OF DAMAGES AT THE SAMPLE PLOTS OF LEVEL 1 IN 2013 AT THE TERRITORY OF THE REPUBLIC OF SERBIA
}

\author{
Goran $\check{C} E \check{S} L J A R^{1}$, Renata GAGIĆ SERDAR ${ }^{1}$, \\ Ilija ĐORĐEVIĆ ${ }^{l}$, Zoran PODUŠKA ${ }^{1}$, Tomislav STEFANOVIĆ ${ }^{l}$, \\ Svetlana BILIBAJKIĆl, Radovan NEVENIĆ ${ }^{1}$
}

\begin{abstract}
The vitality of a forest ecosystem to a great extent depends on the effect of different factors of stress, be it of biotic (harmful insects, phytopathogenic fungi, etc.), abiotic (frost, drought, high temperatures, etc.) or of anthropogenic origin (human activities). Some factors owning to their long-lasting effect can lead to the weakening of the individual trees or the whole forest ecosystem and eventually cause the mortality of it.

The paper presents the results of the research of the types of damages of biotic, abiotic and anthropogenic origin at the sample plot of LEVEL 1 in the Republic of Serbia, conducted during 2013. By the analysis of the data, the results concerning the total number of trees with the identified types of damage, the part of the tree on which the some type of damage occurred most commonly, total number of the trees without any damage, most frequent type of damage and the types of trees with the highest and lowest percentage of damage, were obtained. The results which were obtained present the factual situation regarding the types of the damages for each sample plot and can be beneficial for the further analysis. By comparing these data with the date from other countries, the conclusions about the way in which the vitality of trees depend on the environmental conditions were made.
\end{abstract}

Key words: sample plots, vitality of trees, types of damages.

\footnotetext{
${ }^{1}$ Institute of Forestry, Kneza Viseslava 3, Belgrade, Serbia e-mail: cesljargoran@gmail.com

Translation: Marija Stojanović
} 


\section{ANALIZA TIPOVA ŠTETA NA BIOINDIKACIJSKIM TAČKAMA NIVO-A 1 U 2013 GODINI NA TERITORIJI REPUBLIKE SRBIJE}

Abstract: Vitalnost jednog šumskog ekosistema u velikoj meri zavisi od uticaja različitih faktora stresa., bilo da su biotičkog (štetni insekti, fitopatogene gljive itd.), abiotičkog (mraz, suša, visoke temperature itd.) ili antropogenog porekla (ljudske aktivnosti). Pojedini faktori svojim dugotrajnim delovanjem mogu dovesti do slabljenja pojedinačnih stabala ili čitavog šumskog ekosistema i na kraju izazvati njihov mortalitet.

$U$ radu su prikazani rezultati istraživanja tipova šteta biotičkog, abiotičkog $i$ antropogenog porekla na bioindikacijskim tačkama NIVO-a lu Republici Srbiji, sprovedenih tokom 2013 godine. Analizom podataka dobijeni su rezultati o ukupnom broju stabala sa identifikovanim tipom štete, najčešće zahvaćenog dela stabla nekim tipom štete, ukupnom broju stabla bez štete, najzastupljenijem tipu štete $i$ vrstama drveća sa najvećim $i$ najmanjim procentom štete. Dobijeni rezultati daju činjenično stanje o tipovima šteta za svaku bioindikacijsku tačku i mogu biti pogodni za dalju analizu. Poređenjem ovih podataka sa podacima durgih zemalja mogu se doneti zaključci o zavisnosti vitalnosti stabala od uslova sredine.

Ključne reči: Bioindikacijske tačke, vitalnost stabala, tipovi šteta.

\section{INTRODUCTION}

The intensive monitoring of different adverse effects on the forest ecosystems is carried out every year during the growing season within ICP Forests Programme, which implies that based on the crown condition (defoliation and discolouration), which is generally the most widely applicable indicator of vitality of forests, the percentage of damage is determined. The parameters which are assessed during the evaluation of the crown condition imply the damages by the biotic, abiotic and anthropogenic factors detected on all parts of the tree. Based on the damage which was made, it is possible to assess the causes of the damages of the individual tree or the whole forest ecosystem and derive conclusions about the causal relations. Based on the methods by ICP Forests Programme ${ }^{1}$, the damages on the trees were assessed in three steps: description of symptoms, determination of causes and the quantification of them (ICP Forests 2010). For each tree, several symptoms, which should reflect its health condition, can be described. The description of the symptoms is aimed at the description of the visible types of damages on each individual tree, i.e. pointing to the parts which are damaged, as well as to the type of the observed symptom. The description is focused on the factors which are clearly most dominant and can affect the condition of the whole tree. The symptoms are groupped in categories based on the part of the tree where they occur (Fischer R., Lorenz M. et al. 2012): leaves or needles (deformations, indicators of insects, indicators of fungi, etc.), branches or shoots and buds (wounds, deformations, indicators of insects, indicators of fungi, etc.) and bole

\footnotetext{
${ }^{1}$ International Co-operative Programme on Assessment and Monitoring of Air Pollution Effects on Forests.

International cooperative programme aimed at the evaluation and monitoring of the effect of air pollution on forests.
} 
(wounds, such as bark fall, deformations, indicators of insects, indicators of fungi, etc.).

For each description it is needed to determine the cause which is of the key importance to the study of the causal relations. The main causes of some type of damage on the trees can occur due to the direct actions of man, insects, fungi, game and cattle, frost, drought, high temperature, fire, local pollutants and other factors. ICP Forests Programme of monitoring is the only system which provides the harmonized and trans-national data on the harmful agents at the annual level (Fischer R, et al. 2012).

Based on the data by Banković S. et al. (2009), the total area covered by forests in the Republic of Serbia is 2,252.400 hectares, which accounts for $29.1 \%$ of its territory, the beech (Fagus moesiaca) is the most common species, followed by Turkey oak (Quercus cerris), sessile oak (Quercus petraea), Hungarian oak (Quercus frainetto), hornbeam (Carpinus betulus), etc. Also, at the sample plots of Level 1 , the above mentioned species are equally distributed, except for the Hungarian oak, which is more frequent than the sessile oak. Within the international programme for the monitoring of the forest condition ICP Forests, the grid of the sample plots $16 \times 16$ kilometers of the Level 1 in the Republic of Serbia was established for the first time in 1988 at about 150 sample plots (Nevenić $R$. et al 2009). Afterwards, the forest condition was not evaluated for a long period of time, and the practice was renewed in 2003, and in the following 2004, the new 27 plots in the grid $4 \times 4$ kilometers were added to the existing grid $16 \times 16$ kilometers, in order to gain the most representative data possible on the forest condition in Serbia. Over the previous few years, the studies have been conducted at 121 sample plots, out of which 72 are placed in the state-owned forests, and 49 in the privately-owned forests. Based on the national forest inventory, 49 tree species were determined at the territory of the Republic of Serbia, where the broadleaf species (40) are more dominant than the conifer ones (9). The total number of tree species which are located at the sample plots of the Level 1 and which are subject to the intensive monitoring is 33 , out of which 29 are broadleaf species, and 4 conifer ones.

This paper is aimed at the assessment of the types of damages and collection of the as many as possible pieces of information on the causal relations of the damages on the trees in order to enable the better interpretation of the uncharacteristic instances of mortality.

\section{MATERIAL AND METHOD}

This paper analyses the data collected during the research which was conducted within the regular survey of the Sample plots (Level 1) at the whole territory of the Republic of Serbia in 2013, over the period of the biological activity of the vegetation (June-September). Each individual tree was analysed and each visible change that was detected was reported. The data on the types of damages were reported based on the causes of their occurrence: from the direct action of man, insects, fungi, game and domestic animals, abiotic agents, wildfires, local pollutants and other factors, as well as the damages which were reported but the cause of which was not identified. By the data processing, the results regarding the 
total number of trees with the identified type of damage, the part of tree which was most frequently subject to some type of damage, the total number of the trees without any damage, most frequent type of damage and tree species with the greatest and smallest percentage of the damage, were gained. The research was made at all 2,794 trees within the permanent sample plots of the grid of the sample plots of the Level 1, out of which the total number of broadleaf trees was 2,456, and the total number of conifer ones was 338 .

\section{RESULTS AND DISCUSSION}

The causes of damages in forests can be different (biotic, abiotic or anthropogenic) and can be divided into the ones which make the small damages, great or catastrophic ones, the damages that occur frequently or occasionally, and the ones which can occur at small or great territories. Some damages cannot be always interpreted as the damages since it is known that trees is the home to a great number of insects which live and depend on them. However, the insects by their outbreak can significantly contribute to the physiological weakening of the trees which have already been weak, due to, for instance, drought, i.e. lack of moisture and high temperatures, which to a great extent can aggravate and mask the detection of the real cause of the damage. The visible symptoms can play an important role in the detection and assessment of the different factors of stress. Nevertheless, there are numerous difficulties regarding the interpretation of the visible symptoms since they can considerably vary among the different tree species (Pierre V. et al 2005). The identification of the diagnosis of a very damage will also depend on the cause, i.e. defion of symptoms. Due to the all above mentioned factors, it is very important to be familiar with the symptoms so that the damage will be the least possible and the necessary measures of protection will be applied.

In 2013 the condition of the trees at 121 sample plots of the Level 1 was assessed. Some types of the damages, based on the cause of occurrence, were reported on the 685 trees, out of the total 2,794 trees, which accounts for $24.5 \%$, whereas no indicators of the damage were reported on the remaining 2,019 trees. The trees on which the damages occurred on the crown accounted for $76.4 \%$, the trees with the symptoms on the bole accounted for $16.2 \%$, the trees with the symptoms on the butt accounted for $2.6 \%$, the trees with the symptoms on the whole tree accounted for $3.4 \%$, whereas the trees with the symptoms on both bole and crown accounted for $1.5 \%$ of trees (Figure 1).

The most damages were reported on the crown (leaves) and were caused by the insects, most frequently by defoliators, mostly by the gypsy moth (Lymantria dispar $L$ ), which in the year of the study caused the defoliation at the great areas covered by forests in Serbia (Tabaković-Tošić M. et al 2013). On the bole the mechanical injuries, occurrred by the use of the mechanisation, used for the works in forests, as well due to the felling and the fall of the trees in vicinity, caused by man. The damages on the roots and butt of the tree, made by the machines used for the felling and transport of logs across the fores, are frequent. Also, a great number of cankers caused by fungi is present on the bole, whereas on some trees the damage was reported, but the cause was not identified so it was classified as other damages (Figure 1). 


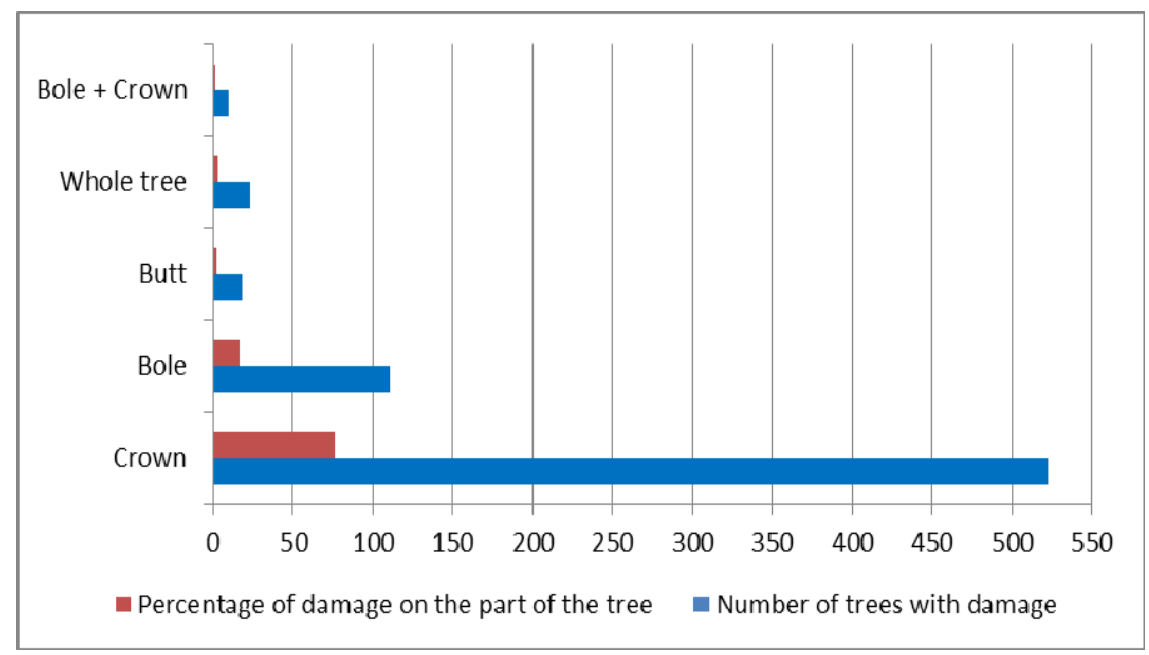

Figure 1. The frequency of some type of damage at some part of the tree

Some visible changes, such as cankers, dry branches, swellings, mechanical damages, etc. were also reported over the previous years during the regular survey of the sample plots, but due to the monitoring of their progression were incorporated in the analysis, since they reflect the current condition of each individual tree. It is important to note that the fungi which cause the rot of the living trees penetrated deep in the interior of the trees mostly via surface wounds on the bark, dry branches, ingrown knobs, etc. (Karadžić D. 2010). Therefore, these pieces of information reflect the health condition, so the observed symptoms are not merely treated as the damages in the narrow sense.

The insects are most frequent agents of the damages in 2013, since they account for 50 percentage, i.e. reported at the total of 343 trees, followed by the other damages, i.e. the damages which were reported but the cause was not identified, which account for $23 \%$, or the total of 157 trees. Humans, i.e. the activities of them, caused the damages on 58 trees, i.e. they account for $8.5 \%$ of the damaged trees. In spite of the great number of wildfires which occurred in the year of the study, the damage made by this agent was reported on only 5 trees of the sample plots of the Level 1, which account for $0.7 \%$. The smallest percentage of the damages on the trees was caused by the game, i.e. $0.1 \%$, or only on one tree. During the year of the study, the increase of the damages caused by the abiotic agents, mainly by the long-lasting drought (Češljar G. et al. 2013), which was also reflected in the mass occurrence of the desiccation of the forests, covering $13,885.00$ hectares of the whole territory of the Republic of Serbia, (Jančić, 2013), was also observed. The trees with the damages occurred as the result of the abiotic factors account for $7.7 \%$, and the drought and frost are the most frequent agents of the damages in this group of agents. The above mentioned data can be seen in the Figure 2. 


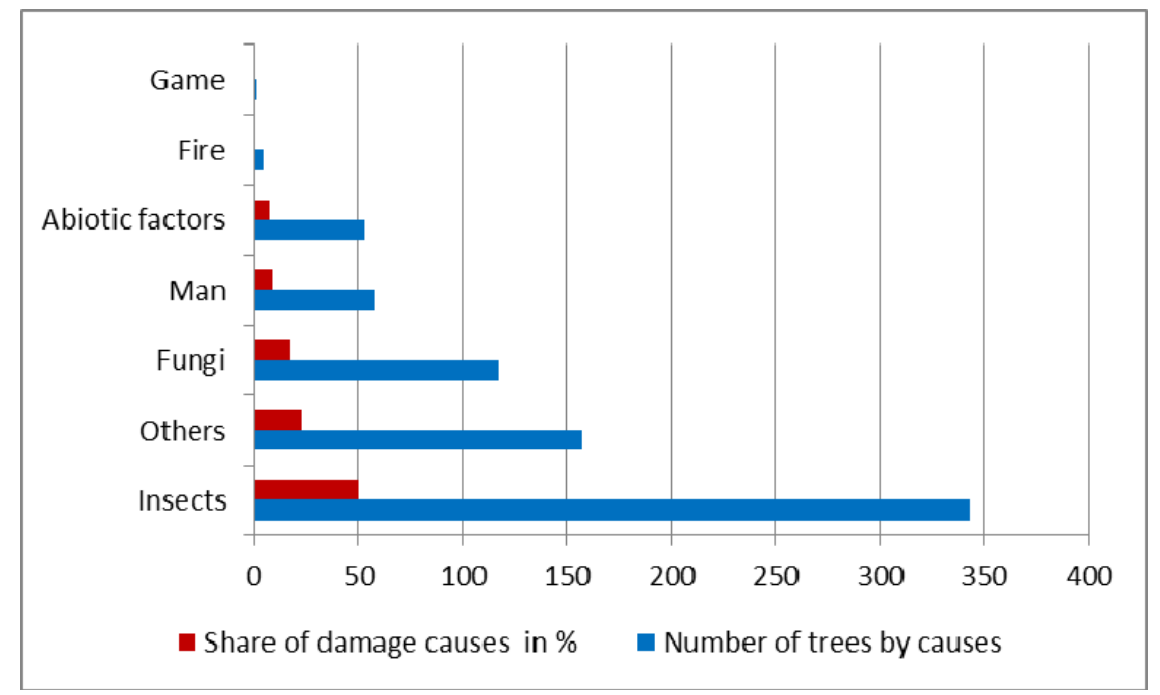

Figure 2. The agents of damages on the trees

In the Figure 3 the tree species with the identified damage and their share in the sample plots are presented, whereas the species on which no changes were detected were classified as the other species. Regarding the number of trees at the sample plots, the most frequent types of the damages were reported on the broadleaf species, such as the beech (Fagus moesiaca) and oaks (Quercus sp.), which implies that the damages are not merely connected to the specific species, but they are more frequent due to the greater density of these species at the sample plots in comparison with other ones. Regarding the conifer trees, the greatest number of some types of damage was reported on the Austrian pines (Pinus nigra) trees, since the small number of trees of the most frequent conifer species at the sample plots, the spruce (Picea abies), sustained some type of damage.

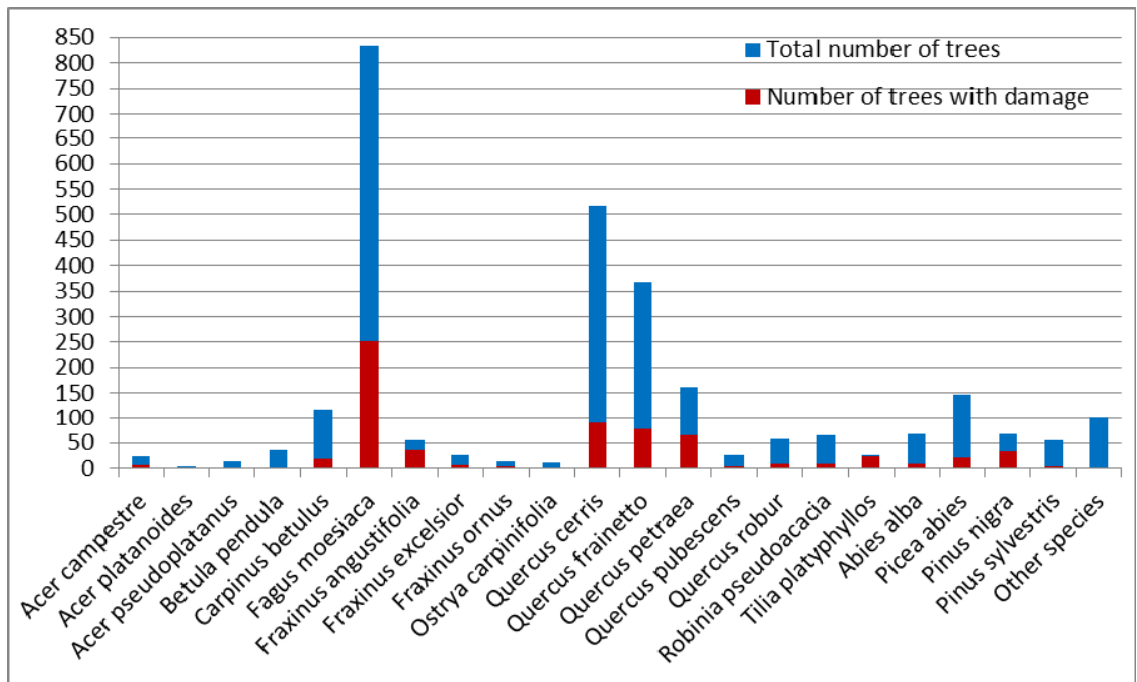

Figure 3. The total number of tree species and number of trees with the damage at the sample plots 
In the Map 1 the distribution of the sample plots of Level 1 at the territory of the Republic of Serbia with the share of the damages on each of them indvidually is presented. The presented data point to the fact that the sample plots with the greatest share of the damages were mainly caused by the insects, such as the case with Eastern Serbia, where the gypsy moth (Lymantria dispar L) caused great damages. It is also important to note that some insect species enterely depend on certain host plant, thereby their greater occurrence at some sample plots correspond to the spatial range of the plant, which can be also noted for some fungi. However, humans at some sample plots owning to the lack of the necessary silviculture measures, mainly regarding the forests, contributed to the occurrence of the greater damages by the insects and fungi, on the both broadleaf and conifer trees, because of which in the future it is needed to apply more frequent monitoring of the forests and silviculture measures so that the damages will be reduced to the least possible level.

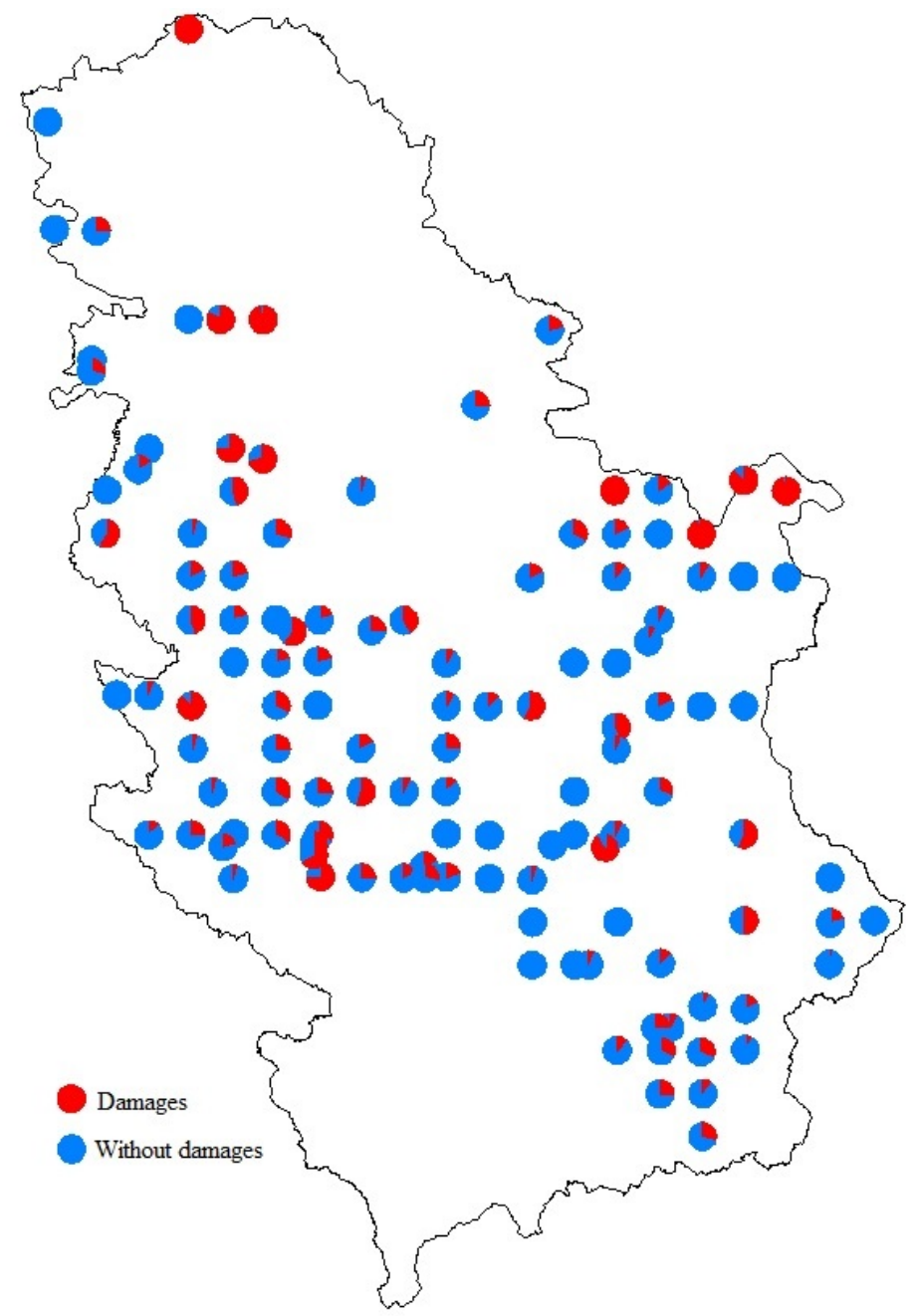

Map 1. Distribution of the sample plots of the Level 1 with the share of damage 


\section{CONCLUSION}

The results which were obtained reflect the most frequent types of damages on the trees at the sample plots which to a great extent can present the current condition of forests in the Republic of Serbia. The presence of some types of damages on the trees is the usual process in the forests, but the occurrence of the high percentage of some of them cannot be always considered to be the natural or usual phenomenon, so it can imply the disturbance in the environment. By the survey of the condition of forests using the method of the sample plots in 2013, the results showing that some visible damages on the trees occurred much earlier than over the year of the study, as the result of the activity of a series of factors of biotic and abiotic origins, as well as of the anthropogenic actions, were analysed and gained. On the one hand, some symptoms were hardly visible, but persistant and progressive, by becoming clearly visible only after some years. On the other hand, some symptoms occurred suddenly. In many cases no biotic factor, which would be able to cause the sudden changes of the health condition of trees, was reported, whereas the abiotic factor such as the drought (very high temperatures and lack of precipitation) was very dominant and probably led to the physiological weakening of the trees, which served as the favourable base for the attack of the secondary species.

The analysis of the types of damages and their agents, during the observed period will serve as the starting point for the evaluation of their effect on the health condition of the individual trees and the whole forest ecosystem. Based on the results of the research, it can be concluded that a great number of factors can affect the health condition of trees, since over the previous few years the climate change, i.e. the unusual weather conditions, can be undoubtedly singled out as the most influential ones.

Acknowledgements: The research is financed by the Ministry of Science and Technological Development of the Republic of Serbia, Project TR 31070 "The development of technological procedures in forestry with a view to an optimal forest cover realisation" (2011-2014).

\section{LITERATURE}

Banković S., Medarević M., Pantić D., Petrović N., Šljukić, B., Obradović S. (2009): The Growing Stock of the Republic of Serbia - State and Problems. Bulletin of the Faculty of Forestry 100: 7-30. ISSN: 0353-4537

Banković S., Medarević M., Pantić D., Petrović N. (2008): National Forest Inventory of the Republic of Serbia. Journal Forestry, Belgrade. p 1-16

Češljar G., Nevenić R., Bilibajkić S., Stefanović T., Gagić Serdar R., Đorđević I., Poduška Z. (2013): Viability of trees on bio-indicator plots level lin Republic of Serbia in 2013. Sustainable Forestry, Collection 67-68, pp. 69-77, Institute of Forestry, Belgrade. ISSN 1821-1046 
Fischer R, Peter Waldner, Jofre Carnicer, Marta Coll, Matthias Dobbertin, Marco Ferretti, Karin Hansen, Georg Kindermann, Petra Lasch-Bor., Martin Lorenz, Aldo Marchetto, Stefan Meining, Tiina Nieminen, Josep Peñuelas, Pasi Rautio, Christopher Reyer, Peter Roskams , Gerardo Sánchez (2012):The Condition of Forests in Europe-Executive Report. p. 4-17. Germany. ISSN 1020-587X

Fischer R, Lorenz M (eds.). (2012): Forest Condition in Europe, 2012 Technical Report of ICP Forests. Work Report of the Thünen Institute for World Forestry 2012/1. ICP Forests, Hamburg, 2012, 165pp.

Jančić G., (2013): Causes of Dieback and Rehabilitation Measures. Review "Šume" PE "Srbijašume", No. 120, pp. 10-11, Belgrade. ISSN 0354-298X

Karadžić D. (2010): Forest Phytopathology. Faculty of Forestry, Belgrade,p 5-774. ISBN 978-86-7299-177-2

Nevenić R., Tabaković-Tošić M., Rakonjac LJ., et al. (2009): Some Indication of Forest Vitality in Republic of Serbia 2004 - 2008. Monography 2004-2008, Institute of forestry, Belgrade. p 7-133

ICP Forests (2010) Manual on Methods and Criteria for Harmonized Sampling, Assessment, Monitoring and Analysis of the Effects of Air Pollution on Forests. UNECE, ICP Forests, Hamburg. ISBN: 978-3-926301-03-1, [http://www.icpforests.org/Manual.htm]

Pierre V., Madeleine S. G.-G. (2005): Diagnosis of Abiotic and Biotic Stress Factors using the Visible Symptoms in foliage. Environmental Pollution 137 (2005) 455-465.

Tabaković-Tošić M. et al (2013): Izveštaj u oblasti dijagnostike štetnih organizama i zaštite zdravlja šumskog bilja na teritoriji Republike Srbije, bez teritorije autonomne pokrajne Vojvodine, u 2013. godini. Institut za šumarstvo, Beograd. http://www.forest.org.rs/pdf/Izvestaj-IDPS-2013.pdf 